\title{
Advergames: uma nova forma de se fazer publicidade
}

\author{
Advergames: a new way of advertising
}

\section{Advergames: una nueva manera de se hacer publicidad}

\author{
Luci Mendes de Melo Bonini ${ }^{1}$ \\ Gilbson Fonseca ${ }^{2}$
}

Palavras chave:

Advergame

Linguagens híbridas

Coca Cola Zero

Publicidade no

ciberespaço

Semiótica

Resumo:

O objetivo deste trabalho é analisar um advergame, ou game publicitário oferecido ao consumidor que esteja conectado à internet. Os estudos teóricos sobre publicidade na internet ainda estão em processo, em construção, e a utilização deste tipo de publicidade teve explosão nos últimos anos, mas apesar da ampla propagação da internet, a sua lógica, linguagem e limites ainda não são completamente compreendidos. Os advergames apresentam-se como uma mídia híbrida, uma ferramenta promissora para profissionais da área que enfrentam uma crise na publicidade tradicional. A presente análise atenta para o jogo publicitário "O impossível é possível: minha vida de game" da Coca Cola Zero que conta a história de um jovem buscando tempo para poder estar com os amigos e com a namorada. Algumas questões emergem neste percurso: de que forma o ciberespaço tem sido utilizado para novas plataformas e linguagens publicitárias? Em que medida as narrativas dos games atuais se parecem com as narrativas dos romances na construção do herói? Como os processos sígnicos são construídos para a identificação com o público-alvo no advergame objeto desta pesquisa? Os autores que norteiam este trabalho são: Bakhtin (1997); Castells (2001); Santaella (2002 e 2005); Jung (2008), Correia e Pereira (2009); Nesteriuk (2009); Santaella e Feitoza (2009); Novak (2010); McGonigal (2012); Santaella e Nöth (2012); Mlodinow (2013).Os resultados iniciais nos conduzem a uma compreensão do uso contínuo da referencialidade cotidiana do consumidor jovem, que é um cidadão comum imerso no mundo pósmoderno que tem como o vilão o tempo. A narrativa presente se entrelaça no mundo onde a Coca Zero está inserida para ajudar o cidadão (herói) e instaurar uma realidade em que a felicidade está sempre presente. 


\section{Resumen:}

Los estudios teóricos de la publicidad en Internet siguen en curso y están dirigidos a un punto de vista más técnico, precisamente porque la Internet es subproducto tecnológico. El uso de este tipo de publicidad tiene una explosión en los últimos años, pero a pesar de la amplia difusión de Internet, la lógica, el lenguaje y los límites no están aún completamente comprendidos. Advergames se presentan como un medio híbrido, una herramienta prometedora para los profesionales que se enfrentan a una crisis en la publicidad tradicional. Este análisis del juego "Lo imposible es posible: mi juego de la vida" de Coca Cola Zero, cuenta la historia de un hombre joven que busca tiempo para estar con los amigos y la novia. Algunas preguntas surgen en esta pesquisa: ¿cómo el ciberespacio se ha utilizado para las nuevas plataformas y lenguajes de la publicidad? Es posible comprender que los héroes de las narrativas de los juegos actuales se parecen con las narraciones de las novelas, los filmes e los romances? Como se construyen los procesos de signos para identificar el público específico para esto tipo de advergames? Los autores que guían este trabajo son: Bakhtin (1997); Castells (2001); Santaella (2002 y 2005); Jung (2008); Correia y Pereira (2009); Nesteriuk (2009); Feitoza y Santaella (2009 ); Novak (2010); McGonigal (2012); Nöth y Santaella (2012); Mlodinow (2013). Los primeros resultados nos llevan a una comprensión de la continuación del uso de la referencialidad cotidiana del consumidor joven, que es un ciudadano común sumergido en el mundo posmoderno, que tiene como villano el tiempo . Esta narrativa se entreteje en el mundo en el que se inserta Coca Cola Zero para ayudar al ciudadano (Héroe) y establecer una realidad que la felicidad está siempre presentet.
Palabras clave:

Advergame

Lenguages híbridos

Coca Cola Zero

La publicidad en el ciberespacio

Semiótica

\section{Keywords:}

\section{Advergame}

Hybrid languages

Coca Cola Zero

Advertising in

cyberspace

Semiotics

\section{Abstract:}

The aim of this study is to analise an advergame. A kind of advertisement offered by some brands on internet. Theoretical studies on internet advertising are still in a developing process in Brazil. The use of this kind of advertising had its explosion in recent years, but despite the widespread of the internet, its logic, language and boundaries are not yet completely understood. Advergames are presented as a hybrid media, a promising tool for professionals facing a crisis in traditional advertising. This paper analysis the advertising game "The impossible is possible: my life as a game", by Coca Cola Zero, which tells the story of a young man seeking time to enjoy with friends and girlfriend. Some questions arise in this way: how cyberspace has been used for new advertising platforms and languages? How is possible perceive the narratives of current games look like the narratives of the novels, the modern soap operas and the movies in the construction of the hero in a game? How the sign processes are constructed to create an identifying process with the target audience in this advergame? Authors who guide this work are: Bakhtin (1997); Castells (2001); Santaella (2002 and 2005) Jung (2008; Correia and Pereira (2009); Nesteriuk (2009); Feitoza and Santaella (2009), Novak (2010); McGonigal (2012); Nöth and Santaella (2012); Mlodinow (2013). Initial results lead us to an understanding of the continued use of everyday referentiality of the young consumer, which is a common citizen immersed in the postmodern world that has as the villain the time. This narrative is a texture that intercept the world where Coke Zero is inserted to help the citizen (the hero) and establish a reality where happiness is always present. 


\section{Advergames: uma nova foma de se fazer publicidade}

\section{Introdução}

Os estudos teóricos sobre publicidade na internet ainda estão em processo em construção, estão voltados mais para uma visão técnica, justamente porque a internet é subproduto tecnológico. A utilização deste tipo de publicidade teve explosão nos últimos anos, mas apesar da ampla propagação da internet, a sua lógica, linguagem e limites ainda não são completamente compreendidos para além dos aspectos tecnológicos, a partir daí, então, novos formatos de propaganda vêm tomando grandes proporções. $O$ interesse no desenvolvimento deste estudo veio na graduação, quando um dos autores obteve bolsa de iniciação científica. Constatam-se, a todo tempo, o surgimento de novas plataformas de publicidade que geram, portanto, novas linguagens, e Castels (2001) observa que:

(...) como em anteriores revoluções tecnológicas, esta transformação sociotécnica abre caminho a toda uma nova gama de produtos com diversos e variáveis graus de adequação entre estes produtos, a procura do mercado e as necessidades sociais. (CASTELLS, 2001, p. 131).

Se a partir desse pressuposto analisarmos a evolução e a rapidez da comunicação publicitária, uma análise de como essa linguagem é construída aplica-se à compreensão de que tais modelos publicitários, além de serem inovadores no sentido tecnológico, apropriados no sentido de criar identidades com o usuário/consumidor e divertidos, na hipótese de uma modalidade publicitária interativa, constroem novos estilos e linguagens na cultura das mídias digitais, fazendo com que os velhos modelos tornem-se saturados. A compreensão desse fenômeno que são os games, em especial os games online e publicitários, enuncia os signos que essa publicidade cria para gerar uma identificação com o público, surgindo uma hibridização nesse formato publicitário, que se apresenta no contexto da propaganda atual.

Em linhas gerais, cabe afirmar que os jogos de publicidade ou advergames (ou ad games) fazem parte desse esforço contínuo de conexão com o consumidor, adequando-se não só à rapidez tecnológica, mas também às novas culturas de consumo e comportamentos gerando sempre novas linguagens no ciberespaço. Santaella (2005) com base na lógica das três categorias peirceanas e seus pressupostos, sintetiza que existem três matrizes da linguagem - sonora, visual e verbal, e, por conseguinte, dentro do ciberespaço o que predomina são as linguagens visuais, incluindo, nesse aspecto, os games publicitários, "e quanto a essa linguagem, sua característica primordial está na insistência com que as imagens singulares, aqui e agora, se apresentam à percepção" (SANTAELLA, 2005, p. 19).

Desse modo, os advergames apresentam-se como uma mídia híbrida e carregados de signos, uma ferramenta promissora para profissionais da área que enfrentam uma crise na publicidade tradicional. Partindo então dessa hipótese, um estudo sobre a contextualização da publicidade e propaganda, nesse caso, os advergames e o potencial comunicativo na construção da linguagem publicitária, mostra-se relevante no campo de estudos sobre internet e cultura digital. O mercado de jogos é o que mais vem crescendo, passando até a indústria do cinema e de automóveis. Nos Estados Unidos $97 \%$ dos jovens dedicam-se a jogos de computador ou videogames (MCGONIGAL, 2012, p. 21).

Nos últimos anos, várias áreas do conhecimento têm se voltado ao estudo de games, assim como: Psicologia, Filoso- 
fia, Ciências da Computação, Engenharia Elétrica, tendo em vista compreender as propriedades desta nova mídia. A internet tornou-se um eficaz meio de comunicação de massa, sendo assim, estudar as mídias presentes neste ambiente pode lançar alguma luz a esta problemática nova.

Por isso, a presente análise atenta para o jogo publicitário "O impossível é possível: minha vida de game" da Coca Cola Zero que conta a história de um jovem buscando tempo para poder estar com os amigos e com a namorada. A Coca Cola Zero está sempre presente para que o personagem beba e assim solicite a ajuda de seus amigos ou de sua namorada para permanecer no jogo. Para tanto, esta pesquisa pretende compreender a construção do personagem-herói, no advergame "O impossível é possível: minha vida de game".

Algumas questões emergem neste percurso: De que forma o ciberespaço tem sido utilizado para novas plataformas e linguagens publicitárias? Em que medida as narrativas dos games atuais se parecem com as narrativas dos romances na construção do herói? Como os processos sígnicos são construídos para a identificação com o público-alvo no advergame "O impossível é possível minha vida de game"?

Os autores que norteiam este trabalho são: Bakhtin (1997); Castells (2001); Santaella (2002 e 2005); Correia e Pereira (2009); Nesteriuk (2009); Santaella e Feitoza (2009); Novak (2010); McGonigal (2012); Santaella e Nöth (2012); Mlodinow (2013).

Os resultados iniciais nos conduzem a uma compreensão do uso contínuo da referencialidade cotidiana do consumidor jovem, que é um cidadão comum imerso no mundo pós-moderno que tem como o vilão o tempo. A narrativa presente se entrelaça no mundo onde a Coca Zero está inserida para ajudar o cidadão (herói) e instaurar uma realidade em que a felicidade está sempre presente. Enquanto nos mitos, os heróis possuem poderes próprios, no advergame esse poder é dado pelo refrigerante, isto é, o imaginário mítico se reproduz adaptando-se às novas tecnologias e, consequentemente, há uma ressignificação da figura do herói.

\section{Advergames: visão geral}

A proliferação de meios de comunicação aconteceu em inúmeros países, ricos e pobres, o que fez com que emergissem inúmeras opções de mídia aos planejadores. "Essa disseminação desenfreada é um dos elementos responsáveis pela revolução que hoje acontece na propaganda e no marketing" (Medeiros, 2009, p.14). E é esta perspectiva que proporciona o surgimento dos jogos com mensagens publicitárias: os advergames.

Alguns games são criados especificamente para divulgar um produto ou um serviço aos consumidores. Os advergames são projetados especificamente como ferramenta de publicidade. "Os games publicitários são usados como alternativa a outras formas de publicidade na web, como os banners" (NOVAK, 2010, p. 81). O primeiro advergame surgiu por volta de 1983 quando a Coca-Cola convocou a Atari e pediu uma versão de Space Invaders para demonstração ao pessoal de vendas em uma convenção. A ideia era substituir as naves inimigas invasoras pelas letras P E P S I e quando o jogador conseguisse derrotar todas as elas, aparecia a frase "Coke wins".

Townsend (apud, Duarte, 2009) explica que advergames

São jogos interativos desenvolvidos inteiramente em torno de uma marca, produto ou evento de marca podendo conter publicidade estática ou dinâmica. Em termos de história, são jogos com relativa facilidade de execução devido 
à necessidade de um canal de distribuição em massa e com custo eficazes. Os advergames são dedicados $100 \%$ a um marca ou produto e tem um share of voice exclusivo. Este tipo de jogo é normalmente fácil de jogar e é constituído por uma dinâmica forte, fazendo com que o jogador queira voltar a jogar (TOWNSEND apud DUARTE, 2009, p. 26).

Basicamente os advergames são jogos publicitários interativos que incorporam uma determinada marca, produto ou serviços e com uma larga facilidade para execução, mais barata, atuando como uma maneira alternativa de comunicação que traz em sua ideologia a persuasão, o entretenimento, a dinamicidade, o envolvimento e a interatividade do jogador para com a marca com o propósito de transformar o mesmo em consumidor promovendo uma forte ligação emocional do jogador com o ambiente.

Quando se cria um advergame, um dos propósitos da marca é a ligação emocional de um jogador com o ambiente, a marca e o jogo como se esses três fossem um só; esta ligação emocional se dá em primeira instância, na construção do herói. O processo de identificação entre o consumidor-jogador se dará como o herói-personagem na busca de suas conquistas. Na verdade, qualquer tipo de game tem esta proposital função; observa McGonigal (2012, p. 37):

um jogo é a oportunidade de focar nossa energia, com um otimismo incansável, em algo no qual somos bons (ou no qual nos tornamos melhores) e apreciamos. Em outras palavras, o jogo é o oposto emocional da depressão.

A autora reafirma ainda que eles são construídos para trazer felicidade, e, portanto quanto mais pendurar o sentimento de prazer, mais a emoção se torna estável.

A Interactive Advertising Bureau, agência americana especializada em conteúdo interativo observa que temos uma predisposição à comunicação interativa (MEDEIROS, 2009). Provavelmente uma das causas que levam as pessoas a buscarem a interatividade é o sentimento de prazer prolongado. Isso seria uns dos motivos crescentes de investimentos em jogos digitais, pois além de prender a atenção do consumidor, veicula as diversas publicidades sem chateá-los. Os argumentos que publicitários usam para convencer os clientes é mostrar que empresas de grande porte estão investindo em jogos: "Coca-Cola, BMW, Sony Ericsson mostrando a abrangência dos games que tem levado as massas a jogarem gradativamente" (MEDEIROS, 2009, p. 15). Ressalta-se, contudo, que a dificuldade maior é convencer os novos anunciantes do quanto jogos digitais dão certo e não são somente para garotos. $O$ advergame constitui atualmente em um dos menores segmentos, porém com o maior crescimento na área de brand entertainment marketing ${ }^{3}$.

Alguns estudiosos afirmam que entre tantos fatores da ascensão de advergames é o fato de a publicidade tradicional estar em crise, outros afirmam que tal fato se dá também com as formas de comunicações mais avançadas. Entretanto, outros fatores, não do surgimento, mas da evolução, seriam as respostas aos baixos níveis de ações sobre os banners de publicidade online, no entanto, vale destacar conforme analisa CORREIA e PEREIRA (2009) a eficácia do advergame vai muito pela notoriedade da marca, sendo eficaz para marcas já conhecidas e relativamente novas para os consumidores, em detrimento de marcas emergentes.

O grande crescimento no número de marcas que tem incluído os advergames como parte de suas estratégias de publicidade, tem sido atribuído a um desejo de envolvimento com um alvo específico de jovens e jovens adultos que estão 
optando pelo mundo online, o que torna o advergame uma maneira única e particular, "pois além de ser específico para determinada marca o próprio jogo é a mensagem publicitária potencializando assim formas interativas a frações e custos mais em conta que as mídias tradicionais" (DUARTE, 2009, p. 21).

Os advergames estão ganhando o seu lugar na publicidade, os jogadores são capazes de interagir com a marca em um ambiente virtual e cheio de entretenimento que ao mesmo tempo é carregado de propaganda, "porém é uma oportunidade única que os consumidores têm de sentir e controlar uma marca efetivamente" (MEDEIROS, 2009 , p. 14). O indivíduo vivencia a marca nesse ambiente algo que ele não poderia fazer com mídias tradicionais desviando a atenção e perdendo até a paciência.

\begin{abstract}
Além disso, devido aos roteiros não lineares e às mecânicas diversas dos jogos, o consumidor fica exposto muito mais tempo à propaganda do que ficaria em uma mídia tradicional, sem perder a paciência. Nas mídias tradicionais, o consumidor pode praticar diversas atividades simultaneamente, dividindo sua atenção. Raramente isso acontece com os games, uma vez que o jogador necessita de concentração total diante dos desafios oferecidos pelo jogo (VEDRASHKO apud MEDEIROS, 2009, p.15).
\end{abstract}

Para MEDEIROS (2009) existem três tipos de níveis de mensagens nos games digitais: associativo4; ilustrativo ${ }^{5}$; e demonstrativo ${ }^{6}$.

Estudos constatam que o nível de recordação e reconhecimento de produtos nesse tipo de jogos é grande, e quando a marca é famosa, o nível de reconhecimento é maior ainda, assim sendo, quando alinhado a uma estratégia de marketing o resultado pode ser bem favorável.
Os advergames são cada vez mais adotados pelas empresas como parte das suas campanhas de marketing. As pesquisas realizadas na área com o intuito de investigar até que ponto os jogadores absorvem as mensagens transmitidas pelas marcas em ambientes interativos, focam-se em jogos de vídeo e ambientes de jogo on-line. (DUARTE, 2009, p. 33).

De acordo com a Advertising AGE 2008, o nível em média de uma marca em exposição no advergame é de 5 a 30 minutos tempo muito maior que na mídia televisiva ou impressa.

\section{Advergames e a construção do lin- guagem}

\subsection{Predominância dos aspectos Indiciais}

Santaella (2002) postula que tudo é um signo: pela qualidade tudo pode ser signo, pela existência tudo é signo e pela lei tudo deve ser signo. Nos games, há o predomínio das imagens como representações visuais para construção do enredo, assim como foi em outras linguagens, desenhos, fotografias, pinturas etc. Nesse contexto, para que haja processos comunicativos é preciso no mínimo três faces "significação ou representação, a referência e a interpretação das mensagens" (SANTAELLA, 2002, p. 59). Assim, na semiótica proposta pela autora, de fundamento peirceano, três são as propriedades do signo - sua qualidade (ícone); sua existência (índice); e seu aspecto de lei (símbolo).

Apesar de as três categorias peircianas estarem em todos os signos, o sin-signo indicial e dicente domina na linguagem visual, no caso deste estudo, os games. Como escreve a autora "O que deve parecer surpreendente e até causar espécie é a postulação de que o nível sin-signo, indicial dicente, domina na linguagem visual" (SANTAELLA, 2005, p. 193). 
Todavia, umas das características do índice é sua função conectora na qual tendem a produzir uma ação física ou mental "os índices chamam nossa atenção, dirigem nossa retina mental ou nos movimentam na direção do objeto que eles indicam" (SANTAELLA, 2002, p. 25). "O índice exerce uma influência compulsiva no intérprete forçando-o a atentar para o objeto indicado" (SANTAELLA, 2005, p. 197). Isso se dá porque os games compartilham entre si, quatro características básicas: meta ${ }^{7}$, regras $^{8}$, sistema de feedback ${ }^{9}$ e participação voluntária ${ }^{10}$. McGonigal (2012, p. 30) conclui que, essa variedade e intensidade do feedback é a mais importante diferença entre os jogos digitais e os não digitais. Em suma, os games são índices por trazer essa característica de conexão e chamarem a atenção imediatamente.

A linguagem gameficada ${ }^{11}$ se estrutura diferentemente das outras mídias por trazer o desafio que o sujeito descobrirá, jogando, daí o convite a aprender conforme se avança na narrativa - "hoje em dia, muitos (se não a maioria) dos jogos de computador e videogames são estruturados dessa forma. $O$ jogadores começam a cada fase enfrentando o obstáculo de não saber o que fazer e não saber como jogar" (MCGONIGAL, 2012, p.35).

Nesse caso, os games sempre trazem o que Santaella denomina de autorreferencialidade, uma multiplicação de intertextualidade, citações, repetições e referências, assim como foi em outras mídias. A autorreferencialidade, afirma a autora: "(...) ocorre quando um discurso, um texto, um processo de signos, de certo modo, com maior ou menos intensidade, refere-se a si mesmo, em vez de se referir a algo fora da mensagem transmitida". (SANTAELLA, 2009, p. 55).

\subsection{Linguagem visual e interpretantes}

A linguagem discutida aqui se refere às formas visuais produzidas pelo ser humano. A linguagem visual, assim como todas as outras, apenas representa, ela faz a mediação entre o homem e a realidade, seu caráter indicial, diferentemente do signo verbal que é arbitrário. Santaella e Nöth denominam de imagens mentais, imagens perceptíveis e imagens como representações: fotografias, imagens cinematográficas, televisivas e etc. "Imagens nesse sentido, são objetos materiais, signos que representam o nosso meio ambiente visual" (SANTAELLA; NÖTH, 2012, p.15). O que os autores propõem discutir é a que as imagens antes de serem físicas, já foram concebidas na mente, portanto, não estando separados desta, e vice versa.

É nesse campo que se encontra a construção de várias representações visuais, a saber, a amplitude das linguagens nas mídias digitais, uma linguagem híbrida:

Games são híbridos porque envolvem programação, roteiro de navegação, design de interface, técnicas de animação, usabilidade, paisagem sonora, da hibridização resulta a natureza intersemiótica dos games, a constelação e intersecção de linguagens ou processos sígnicos que neles se concentram. Todas essas linguagens passam por um processo de tradução intersemiótica, quer dizer, transposição de um sistema de signos a outro, para se adequarem aos potenciais abertos pelas novas tecnologias que são atraídas para a linguagem dos games (SANTAELLA, 2009, p. 10).

Seguindo esta linha, do mesmo modo que os games absorvem as linguagens de outras mídias, estas também permitem ser analisadas à luz da semiótica, pois possuem recursos semióticos e estéticos que lhes são próprios. Por meio dessa definição, quando aplicado ao game publicitário, a análise semiótica tem por objetivo exprimir possibilidades comunicativas que estão, muitas vezes, no design, na narra- 
tiva, no personagem, até mesmo a análise ideológica que as marcas têm a intenção de passar. Daí explora-se, por meio desta análise, quais são os efeitos que um dado produto está apto a produzir em um receptor. Para Santaella (2002), esses efeitos podem ser de várias ordens, desde o nível de uma primeira impressão até o nível de um julgamento de valor que o receptor pode e, muitas vezes, é levado, a efetuar.

Por serem publicidade em movimento, os games funcionam, muitas vezes, como uma espécie de laboratório de novas linguagens e tecnologias (NESTERIUK, 2009). Nesse sentido, a ação do signo funciona como mediador entre o objeto e o efeito que o signo produz em uma mente atual ou potencial, para Santaella:

O signo funciona como mediador entre o objeto e o efeito que ele está apto a produzir em uma mente porque o signo, de alguma maneira representa o objeto (...) o objeto é algo distinto do signo e isso explica porque o signo não pode substituir inteiramente o objeto, pode estar apenas no lugar do objeto, representá-lo indicá-lo para a idéia ou interpretante que o signo produz ou modifica. (SANTAELLA, 2005, p.191).

Os signos dos games, por causa deste hibridismo, podem produzir diversos efeitos em uma mente interpretadora, pois o interpretante de um signo é sempre múltiplo. As relações que o signo estabelece entre o objeto e a mente interpretadora chama-se interpretante. $O$ interpretante imediato é aquele que o signo está apto a despertar numa mente interpretadora, e interpretante dinâmico, é o que o signo realmente desperta. A seguir se discute a construção do herói no game, de modo que se possa compreender que o interpretante imediato: o herói cotidiano, expresso na narrativa do game, pode ser de uma certa maneira e num certo sentido o inter- pretante dinâmico, uma vez que retoma a já conhecida receita do mito do herói.

\section{Advergames e a construção do personagem}

\subsection{O herói do imaginário versus o herói do cotidiano}

Teorizar a figura do personagem nos games traz uma complexa discussão da forma como a heroificação é constituída na sociedade e pelos meios de comunicação. Assim, como em toda cultura a figura do herói está presente na psique humana, revelando-se como representações simbólicas, que além de afirmar a personalidade do indivíduo converge na afirmação da identidade de um grupo social. JUNG (2008, p. 112) sintetiza que essas representações são "entidade maior e mais ampla que supre o ego da força que Ihe falta. Sua função específica lembra que é atribuição essencial do mito heróico desenvolver no indivíduo a consciência do ego" isto é, o conhecimento de suas próprias forças e fraquezas.

O que Carl Jung defendia era a ideia de que, para aprender sobre a experiência humana, era importante estudar os sonhos e as mitologias, pois estes eram expressões profundas do ser humano. Os temas e arquétipos dos sonhos e mitos, esclarece Jung, transcendem o tempo e a cultura; surgem a partir de instintos inconscientes que governaram o comportamento muito antes de serem revestidos e esquecidos, e, portanto, ensinam o significado de ser humano no nível mais profundo.

Mlodinow aponta que "possuímos uma mente inconsciente e, superposta a ela, um cérebro consciente. Quantos de nossos sentimentos, juízos e comportamentos se devem a cada uma dessas estruturas (MLODINOW, 2013, p.19). Para o autor boa parte das ações humanas está 
no inconsciente, mesmo que a ideia prevalente, seja ao contrário.

Os estudos sobre o inconsciente se modernizaram, e se tornou mais amplo do que teóricos como Freud acreditavam. Para Mlodinow (2013, p. 28): "O comportamento humano é produto de um interminável fluxo de percepções, sentimentos e pensamentos, tanto no plano consciente quanto no inconsciente". Assim, a noção de não estarmos cientes da causa de boa parte do nosso comportamento pode ser difícil de aceitar. Esse inconsciente contém temas e arquétipos universais que irão aparecer em nossa cultura na forma de histórias e tipos de personagens presentes na arte, literatura, nos filmes e nos games. Os significados dessas imagens acabam tendo o mesmo sentido em qualquer lugar ou época, e o seu significado é comum não somente nas lendas, mas também nos mitos, apresentando personagens em situações similares.

Essas típicas formas de conceber uma imagem arquetípica são semelhantes, e como existem no inconsciente coletivo, elas são imaginadas fisicamente pelo ser humano. Confirma que esses padrões são usados em todos os meios de entretenimento para reforçar a conexão do público com a história (NOVAK, 2010). A composição do herói que existe no imaginário cultural, e nos mais diversos games mercadológicos ou não, é uma releitura de mitos, presente na mitologia grega, fábulas e contos, assinala Rahde:

se os mitos, as fábulas e os contos de fadas sempre estiveram presente no imaginário, podemos dizer que, no mundo contemporâneo, essas histórias, várias vezes resgatadas pelo cinema, estão sendo cada vez mais revistadas ou recontadas. (RAHDE, 2008, P. 99)

É na ficção, observa Rahde que “(...) o imaginário se desenvolve e enfatiza elementos que estimulam a ligação com o sujeito, evocando "fantasia, poesia, escapismo, consolo e expressões simbólicas universais" (RAHDE, 2008, p. 101).

O mito do herói é uma apropriação que encontramos nas mais diversas mitologias, o envolvimento com o mito do Herói sempre se repete, o nascimento humilde, mas milagroso, a prova de sua força, a ascensão rápida ao poder, a luta contra as forças do mal e sua coragem. Jung nos esclarece esse fato "pois tem um poder de sedução dramática e flagrante e, apesar de menos aparente uma importância psicológica profunda" (JUNG, 2008, p. 110).

O herói sempre é apresentado com um problema no começo da história e embarca em uma jornada física e emocional para, finalmente solucionar esse problema. Novak (2010) afirma que ele é responsável pela maior parte da ação, correndo os maiores riscos e assumindo as maiores responsabilidades.

A figura do herói pode ser analisada, de acordo com a semiótica de Peirce, no seu aspecto de sin-signo/indicial, quer dizer, signo como existente. Aqui ele deve ser analisado pela suas conexões, significações e associações. Em qual contexto está inserido? Quais as relações entre este contexto e os jogadores? Quais as possíveis interpretações deste signo? Como os jogadores absorvem e interagem com o advergame?

A bebida, Coca Cola Zero, dá ao herói, mais 'vida'. É o fenômeno, como na mitologia que faz com que o herói possa vencer seus obstáculos. O jovem, personagem-herói, precisa vencer seus obstáculos que o impedem de ter mais qualidade de vida, e a poção mágica que the garante o poder é o refrigerante. Necessário se faz destacar neste percurso, que a Coca cola é sem açúcar, logo a magia está na fórmula mesma, e não na química do açúcar para gerar energia. 
O interpretante imediato, ou o que o signo está apto a despertar na mente dos sujeitos-consumidores-jogadores é que a juventude obtém mais força e energia em sua vida, para o enfrentamento das questões (adversidades, inimigos, obstáculos), se beber o refrigerante. Mergulhado no jogo, uma linguagem híbrida e interativa, o jogador, se identifica com o sujeito, esta identificação-fusão, faz com o herói seja ele mesmo, se confundindo com o herói, confunde-se também com a publicidade que ali se faz. Ideologia do consumo, as vozes do mercado, marcadamente na construção/ identificação do sujeito consumidor-jogador-personagem feito herói.

\section{O Poder da referencialidade no ad- vergame - Signos: herói e Coca Cola}

Para Peirce, a realidade só pode ser representada (SANTAELLA, 2002). Os signos representam, apenas representam a realidade, numa certa medida, por isso, todo complexo que representa a realidade é um signo. Peirce ainda explica, que todo signo que guarda uma relação direta com o objeto, é um signo indicial, por isso, entendemos que o game: "O Impossível é Possível: Minha Vida de Game" é um signo indicial, pois ele representa a trajetória diária de um cidadão comum. Os significados do jogo vão se construindo na medida em que, este cidadão comum, o herói do jogo, vai enfrentando os problemas da realidade dele, os obstáculos, e vai se preparando para uma vida mais plena de alegrias. Assim é a vida do herói, sua missão é eliminar as barreiras que se colocam no caminho para tornar a vida das pessoas mais feliz.

O advergame mostra um herói (símbolo) que indica força, poder, saúde (índice) que está diretamente ligado ao posicionamento da Coca Cola Zero que tem seu público alvo, jovens da geração X. De uma forma geral, a marca Coca Cola Zero posiciona-se para atender a um público que busca uma alternativa mais saudável. Essa geração viveu em uma era de transformações "eles adoram os pais, querem ter sucesso, são otimistas, confiantes, cooperativos, obedientes e conscientes de seus deveres cívicos" (NOVAK, 2010, p. 65).

Nesse sentido, o advergame foca no propósito heróico, sensação de poder e sucesso que está diretamente ligado às aspirações dos jovens no século XXI. O advergame expõe aspectos de símbolos por apresentar abstrações que estão no inconsciente, o que é típico do games, o herói. $\mathrm{E}$ ao longo do jogo há inúmeras referências ao cotidiano. O advergame centra-se em resgatar e afirmar a ideia de virilidade do herói com corpo musculoso e grande força, na intenção da intertextualidade de outras mídias como os livros (literatura), o cinema e a TV que perpetua o principal personagem com as mesmas características. Entretanto, um ponto particular que encontramos no advergame, é a sua definição enquanto ao controle de poder - diferenciando-o de outras mídias, aqui, o jogador controla o personagem, reafirmado o propósito heróico que o advergame/coca cola se propõe, estabelecendo uma conexão com o avatar, a fusão de que se falou há pouco.

Há, na maioria das histórias, contos de fada e demais lendas que povoam a cultura de diferentes povos uma fraqueza que domina o protagonista em algum momento, em muitos casos, protetores e guardiões aparecem para ajudá-lo a desvendar certos segredos e motivá-lo para seguir em direção a sua missão.

O advergame retoma o imaginário popular ao tentar fazer com que o jogador e o avatar tenham uma conexão emocional ao jogar. De acordo MacGonigal (2012, p. 45) um dos grandes desafios de quem produz um game é arquitetar um percurso que traga felicidade ao jogador. Em resumo, ao resgatar as fábulas e mitos no advergame ela resgata a invencibilidade e a 
imortalidade do herói, causando uma crise de identidade entre o herói da Coca cola zero e o herói da realidade. No advergame, o herói vive em uma cidade grande, enfrenta os problemas do dia a dia com poderes mágicos para destruir os entregadores de panfletos até chegar ao trabalho.

Magalhães e Silva (2007) enfatizam que na abordagem sobre o herói ficcional e o herói político encontram-se o maniqueísmo, a unilateralidade e o sucesso como elementos centrais na construção discursiva do herói no ocidente, posto que, o produto ao apresentar um personagem retirado da realidade do mundo do trabalho, procura ressignificá-lo e, ao mesmo tempo, tenta refletir o cidadão do dia a dia, porém, atualiza as representações inconscientes e ideológicas dos mitos, trazendo um herói habitual, embora, com poderes mágicos dados pelo refrigerante.

Neste caso em estudo, quando o herói consegue beber a Coca - Cola, ele invoca a ajuda de seu melhor amigo, namorada ou do Professor de Karatê - o Sensei, que o auxiliam a enfrentar obstáculos. O jogo tem uma arquitetura semiótica simbólica, ou seja, palavras, imagens e sons se entrecruzam e constroem uma realidade muito semelhante à realidade cotidiana do consumidor de refrigerantes, que cotidianamente enfrenta os desafios da vida. O caráter indicial do jogo reside aí, reflete a realidade, mas ao mesmo tempo que reflete, refrata e distorce, pois o objetivo do advergame é fazer com que o consumidor fique muito tempo em contato com o produto e a marca, levando o a acreditar que ao consumir o produto, ele se tornará um herói também.

Todo enredo do advergame em questão, é constituído a partir de um caminho clássico do mito do herói. (BAHKTIN, 1997)

- Sai do lugar de origem movido ou por uma imposição ou por livre iniciativa, porque ele busca uma transformação.

- Enfrenta obstáculos.

- O herói chega a um lugar onde recebe instrumentos de força. Momento em que vai adquirir ou aprimorar competências.

- Retorna ao ponto de partida e transforma a realidade da qual ele partiu.

Assim como nos romances de prova o protagonista é submetido à prova: "sua lealdade, suas virtudes, suas façanhas, sua magnanimidade, sua santidade etc" (BAKHTIN, 1997, p. 225). O autor ainda afirma que todas as peripécias organizam-se em torno de provocações, tentações e lutas a que ele se subordina a fim de realizar sua missão. Desde os romances de cavalaria, esta fórmula ainda funciona no cinema, nas novelas televisivas e nos games, aproveitar a característica humana de querer ser um vencedor sempre, é uma das ferramentas dos diferentes produtos de entretenimento desde tempos imemoriais.

McGonigal (2012), elucida uma espécie de profecia fundamentada em números gigantescos e estudos psicológicos e antropológicos sobre os games, de que o futuro será bem melhor para as pessoas que jogam. A autora também afirma que "eles oferecem recompensas que a realidade não consegue dar (...) eles estão nos unindo de uma maneira pela qual a sociedade não está" (2012, p. 14).

\section{Considerações finais}

A necessidade de se comunicar através de sons, imagens e textos, aglomerando mensagens e tecnologias multimídia é uma realidade. As mídias se transformam conforme as necessidades sociais, ocasionando a criação de novos mecanismos publicitários.

Os advergames vieram como uma linguagem nova para uma geração que 
sai do mundo real e entra em um mundo virtual. Apropriando-se desse êxodo em massa, marcas como a Coca Cola Zero através da explosão da indústria de games viu nessa mídia um poder de transmitir não somente o produto, mas ideias e convicções, o que na mídia convencional se tornou difícil.

No mundo em que há uma lógica feroz na sedimentação de significados na construção de consumidores, (em que o excesso de informação pode ter efeito deletério nos sujeitos, pelas mensagens publicitárias interativas e demoradas) pode-se obter uma fidelização maior do consumidor.

Com a saturação das mídias tradicionais, a atenção se tornou escassa e, consequentemente, os meios digitais têm sido usados para criação de novas linguagens.

A linguagem da propaganda, seja a tradicional seja a atual, busca lapidar nos consumidores, valores e estilos de vida, que por sua vez, vão criando padrões e cristalizando comportamentos, da mesma forma que as novelas de cavalaria e os romances dos séculos XVII e XVIII.

Sendo assim, ao se analisar "Minha vida de game", percebe-se que há uso contínuo da referencialidade cotidiana do consumidor jovem, que representa a contemporaneidade do cidadão comum, imerso no mundo pós-moderno que se entrelaça no mundo onde a Coca Cola Zero está inserida para ajudar o cidadão (herói) e instaurar um mundo de felicidade.

O advergame em análise mostra a vontade de todos os seres humanos de ter importância na vida de alguém, a vontade de ser amado, e de viver uma aventura que conduza à glória. Assim como em outros games, o imaginário mítico se reproduz adaptando-se às novas tecnologias e, consequentemente, tem-se uma ressignificação da figura do herói.
O desassujeitamento em que se vive, a despersonalização do mundo em que se é apenas mais um rosto na multidão, retoma o mito do herói, e incentiva sua emancipação, pelo menos no mundo virtual um herói adaptado, porque é cotidiano, as princesas e os dragões se metamorfosearam em pessoas comuns: a namorada, a família, o chefe, o batedor de carteiras na rua.

O personagem do advergame é um herói retirado da realidade que se adapta aos anseios do homem (poder, força, imortalidade). O que nos leva a concluir que existe uma abstração que resiste ao tempo, isto é, com toda a expansão do ser humano e racionalidade, os traços heróicos permanecem como padrões na cultura sendo usados como motivação de venda pela coca cola zero que se revelará simbolicamente na linguagem do game em toda sua trajetória desde as metas e regras estabelecidas, até as possibilidades interpretativas do jogador que provavelmente será um consumidor. Todavia, é preciso estudos futuros com indivíduos que joguem o advergame para comprovar o que efetivamente a Coca Zero está apta a produzir em uma mente interpretadora, isto é, no outro nível de interpretante, o dinâmico.

\section{Bibliografia}

BAKHTIN, Mikhail. Estética da criação verbal. São Paulo: Martins Fontes, 1997.

CASTELLS, Manuel. A Galáxia internet. Reflexões sobre internet, Negócios e Sociedade. Lisboa: Fundação Calouste Gulbenkian, 2001.

CORREIA, Rosário ; PEREIRA, Francisco C. Advergames em Portugal e estratégias utilizadas, In Congresso SOPCOM, Sociedade dos Media: Comunicação, Política e Tecnologia. Anais, Universidade Lusófona de Humanidades e Tecnologias, Campo Grande. Lisboa. $6^{\circ}$ SOPCOM, 2009. p. $4050-4071$ 
DUARTE, Ana. Adopção da In game Advertising em Portugal. Dissertação (Mestrado em Marketing Management) Instituto Universitário de Lisboa. Lisboa. 2009.

JUNG, Carl G. O Homem e seus símbolos, Rio de Janeiro: Nova Fronteira, 2008.

MAGALHÃES, Hilda G. D. ; SILVA, Luíza, H. O. Do herói ficcional ao herói político. Revista Multidisciplinar Ciência e Cognição UFRJ. Rio de Janeiro. 18- 30 v.12, 2007.

MARTINS, José D. S. O senso comum e a vida cotidiana. Revista Tempo Social, Revista de Sociologia da USP. São Paulo 1-8, v.10 n 1, 1998.

MEDEIROS, J.F. Advergames: A publicidade em jogos digitais como forma de atrair o consumidor. In: VIII Brazilian Symposium on Games and Digital Entertainment - Rio de Janeiro, 2009.

MCGONIGAL, Jane. A realidade em jogo: por que os games nos tornam melhores e como eles podem mudar o mundo. Rio de Janeiro: BestSeller, 2012.

MLODINOW, Leonard. Subliminar: como o inconsciente influencia nossas vidas. Rio de Janeiro: Zahar, 2013.

NESTERIUK, Sérgio. Reflexões acerca do videogame: algumas de suas aplicações e potencialidades. In: Lucia Santaella, p. Mirna Feitoza. (Org.). Mapa do Jogo - A diversidade Cultural dos Games. 1ed. São Paulo: Cengage Learning, 2009. p. 23-36.

NOVAK, Jeannie, Desenvolvimento de games. São Paulo: Cengage Learning. 2010.

RAHDE, Maria F. Comunicação e imaginário nos contos do cinema contemporâneo: uma estética em transição, Revista Comunicação, Mídia e Consumo, ESPM. São Paulo, v. 5 n. 12, 2008

SANTAELLA, Lucia. Matrizes da Linguagem e pensamento: sonora, visual e verbal. São Paulo: Iluminuras, 2005.

Semiótica Aplicada. São Paulo: Pioneira Tomson, 2002.

SANTAELLA, Lucia ; NÖTH, Winfried. Imagem, Cognição, Semiótica e mídia. São Paulo: Iluminuras, 2012.

SANTAELLA, Lucia ; FEITOZA Mirna. (ORG) O mapa do jogo: a diversidade cultural dos games. São Paulo: Cengage Learning, 2009.

1 Coordenadora do Mestrado em Políticas Públicas da Universidade de Mogi das Cruzes. Contatos: Iucibonini@gmail.com

2 Bacharel em Publicidade pela Universidade de Mogi das Cruzes. Agradecimentos: Ao CNPq pela Bolsa de Iniciação Científica recebida.

3 O "brand entertainment" como forma de comunicação e de fazer as marcas chegarem aos consumidores encontra-se em expansão e, além do entretenimento que proporcionam, apresenta vantagens para a marca, tais como baixos custos de produção e colocação de mensagens da marca e ainda a possibilidade de realizar o tracking da audiência caracterizando-a segundo o número de visitas, o tempo despendido na visita ao site e o número de revisitas (entre outros indicadores). Neste sentido, os advergames aparecem como uma forma híbrida de brand entertainment (DEAL apud CORREIA e PEREIRA, 2009, p. 4051)

4 O mais fraco, "pois se assemelha com a publicidade convencional, a marca é levemente associada ao estilo ou atividade proposta em um jogo já existente, o uso de outdoors, logomarcas replicando a publicidade do mundo real" (MEDEIROS, 2009, p.14).

5 "Onde a marca é fortemente associada ao jogo seja por itens patrocinados no ambiente virtual ou promoções da empresa para o jogador nesse caso a marca não é apenas vista, ela passa a interagir com o jogador". (MEDEIROS, 2009, p. 14)

6 "O que seria o mais interativo possível, onde a marca faz parte integral do jogo interagindo com o consumidor de forma persuasiva" (MEDEIROS, 2009, p.14).

7 É o resultado específico que os jogadores vão trabaIhar para conseguir (...) a meta propicia um senso de objetivo (McGONIGAL, 2012, p 30)

8 Impõe limitações em como os jogadores podem atingir a meta. (...) Elas liberam a criatividade e estimulam o pensamento estratégico (id.,ib., p 31)

9 Diz aos jogadores o quão perto eles estão de atingir a meta. O sistema pode assumir a forma de pontos, níveis, placar ou barra de progresso. (id.,ib., p. 31)

10 Exige que o jogador aceite conscientemente e voluntariamente, a meta, as regras e o feedback

11 Linguagem dos games 